\title{
SERVANTS AND HANDS: REPRESENTING THE WORKING CLASSES IN VICTORIAN FACTORY NOVELS
}

\section{By Dorice Williams Elliott}

EARLY IN Frances Trollope's 1839 novel The Life and Adventures of Michael Armstrong, the Factory Boy, the title character is introduced into the kitchen of Sir Matthew Dowling's home. The assembled servants, rigidly organized into their own hierarchy of status and position, react with horror and derision at the very idea of a factory boy joining the household on any terms. The only way in which they can explain such a preposterous idea is to speculate that the boy is Sir Matthew's illegitimate son; only by inventing a hidden genealogy can they imagine a place for a factory worker in the genteel British home (Figure 2).

The servants depicted in Michael Armstrong derive their sense of position in Sir Matthew's house not only from their current situations, but also from their past employment by, and hence familiar association with, other aristocratic or wealthy masters. Their allegiances and loyalties, therefore, lie far more with their employers and fellow servants than with other groups of working-class people. In fact, Sir Matthew's servants define their own identities in opposition to other kinds of workers, especially factory workers. On Michael's first appearance in the kitchen, the servants perceive him as an alien, even non-human form: "at least half-a-dozen servants had assembled there, all of whom were gazing at little Michael, very much as if he had been caught in a forest, and conveyed thither to gratify their desire of studying natural history" (25; ch. 3). The housekeeper, reigning queen of the below-stairs household, further emphasizes Michael's otherness as a factory boy:

"A factory-boy, certainly," she replied with the dignity that was peculiar to her, "nobody is likely to doubt that, Mr. Macnab; one might know his calling at half a mile's distance. The vulgar factory itself, with its millions of windows, is not more easily known than the things that crawl out of it, with their millions of cotton specks - that is not the main point of the question, Mr. Macnab: it is not what the boy is, but who he is, and for what reason any one has dared to say that he was to sup in the servants' hall." (26; ch. 3$)$ 


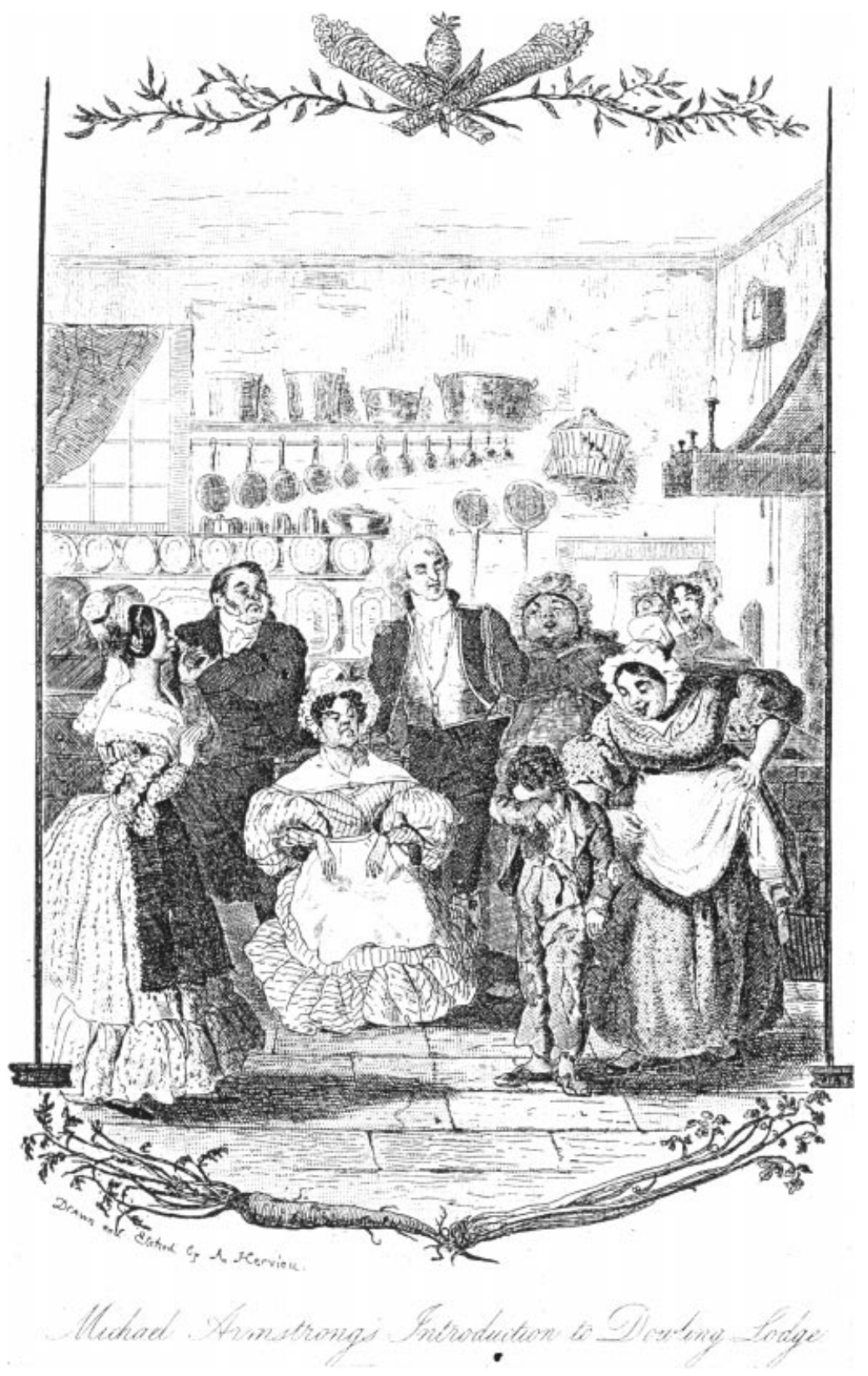

Figure 2. Auguste Hervieu, "Michael Armstrong's Introduction to Dowling Lodge." 1840. Etching, from Francis Trollope, Life and Adventures of Michael Armstrong, Factory Boy. (Newcastle-onTyne: Christie, 1876.) 
To these servants, Michael's "calling" is manifest, the cotton fluff in his hair registering not only his job, but "what" he "is" - uncouth, reptilian, and, because he stands in for and represents the "vulgar" many-windowed factory, unmistakably different from the respectable servants. The dignified Mrs. Thompson defies even her master's right to conflate servants with factory boys, though both, of course, are his paid employees.

Many of the middle-class readers who would have read Trollope's novel probably shared the servants' discomfort at the prospect of a "factory boy" in the midst of a middle-class home. Servants, of course, were an integral part of the familiar world these readers lived in; employing servants, in fact, has often been used by historians as the standard of middle-class status in Victorian England (Valenze 169; Robbins 15). Factory workers, on the other hand, were unfamiliar and vaguely, if not overtly, threatening. Most middle-class people, even many family members of factory owners, had never been inside a factory and had probably never seen a factory worker, except at a distance. In the "hungry forties," when Trollope's novel was published, most people were simply unaware of factory conditions and the lives of factory workers, even though protective factory legislation had already been debated and passed in Parliament.

The attitude of the factory-worker protagonist in Elizabeth Gaskell's Mary Barton (1848), John Barton, may thus have been surprising to many middle-class readers. Barton considers domestic service "as a species of slavery; a pampering of artificial wants on the one side, a giving-up of every right of leisure by day and quiet rest by night on the other" (61; ch. 3). Using the rhetoric of "rights" and "slavery," Gaskell's character scorns workers who would give up their natural independence to "pamper" the "artificial wants" of other humans who only happen to be richer than he is. His daughter Mary likewise looks disdainfully on a life of service that would restrict her independence by forcing her to "submit to rules as to hours and associates, to regulate her dress by a mistress's ideas of propriety, to lose the dear feminine privilege of gossiping with a merry neighbour, and working night and day to help one who was sorrowful" (62; ch. 3). Mary's language asserts that her class has its own ideas "of propriety" and its own network of social relations and privileges and that she and her peers do not need to be regulated by middle-class employers.

While both the servants and factory workers in these two novels seem to define their own positions by their differences from the other, both belong to what many historians, Marxist theorists, and literary critics call "the working class." Not only do they both work at menial labor for a wage, but both also come, in most cases, from the same background - their parents and forebears were rural agricultural workers. ${ }^{1}$ Both have migrated to cities or towns in search of employment and higher wages. Yet, as these examples demonstrate, the two groups experienced quite different working and living conditions, identified themselves with different systems of rank and status, and operated under seemingly different economic systems. Scholarly work on the lives and attitudes of both servants and factory workers has been difficult and relatively scant, since both groups have left far fewer written accounts than their more literate and leisured employers of the middle and upper classes. While a number of historians have done important work recovering firsthand accounts and demographic statistics for these groups, only a few literary scholars have focused on recovering the writings of working-class people or on representations of servants or factory workers in literary texts. Neither historians nor literary scholars, however, have looked closely at the relationship between the two groups. Bruce Robbins's 
important study of literary representations of servants, The Servant's Hand, for instance, hardly mentions factory workers, while works like P.J. Keating's The Working Classes in Victorian Fiction divide the working class into industrial workers and other urban laborers, almost totally ignoring the servant population.

Most of the writers of the group of novels called variously "factory novels," "socialproblem novels," "condition-of-England novels," or "novels with a purpose," on the other hand, do represent both factory workers and domestic servants interacting with or commenting on each other. All of these novels, of course, were written by middle-class authors, so their portrayals cannot be taken as representative of the voices or perspectives of working-class people, whether servants or factory workers; they are, however, clear examples of the way the middle classes constructed and imagined the working-class people they employed in their homes and workplaces. Thus this group of novels is an especially fruitful site for exploring the construction of class and class consciousness in the Victorian era and for demonstrating the cultural work performed by the novel during the period. What these novels collectively demonstrate is that for these middle-class writers, most of whom were women, representing the relationships between servants and factory workers was crucial to their own sense of class and gender identity. In order to ensure their own position of authority and social utility, these writers needed to make evident both the differences and the similarities between workers in the domestic sphere and in the industrial setting.

A number of literary critics have commented on the fact that so many of the prominent nineteenth-century British factory novelists were women. ${ }^{2}$ While Elizabeth Gaskell is perhaps most well-known as a factory novelist, several other women writers, including Frances Trollope, Charlotte Brontë, George Eliot, Harriet Martineau, Charlotte Elizabeth Tonna, Elizabeth Stone, and Geraldine Jewsbury also turned their pens to the depiction of the plight of factory workers. All of these writers, not incidentally, were also mistresses of servants. Having servants, in fact, was a primary condition for women's professional writing; only by employing servants to do the multitude of domestic chores necessary in running a middle-class home could these women have the time to write and to research the factory conditions about which they wrote. ${ }^{3}$ Thus these writers were personally involved with and implicated in the class relations they described and portrayed in their novels.

As the primary employers and managers of servants, middle-class women were in a crucial position in terms of mediating class relations. Although it is widely recognized that during the first half of the nineteenth century factory work brought large numbers of working people to cities and large towns, it is important to recognize that industrialization also created a correspondingly large and rapid increase in the number of people engaged in domestic service. ${ }^{4}$ Historians have generally agreed, in fact, that the number of domestic servants rose sharply in the first half of the nineteenth century, though it declined somewhat after 1870 (Robbins xi; Roberts 29; Sharpe 102). Tilly and Scott estimate that anywhere from a third to half of all nineteenth-century workers were domestic servants (69). 5 Thus, as mistresses of servants, middle-class women hired, supervised, and had daily contact with a substantial and ever-growing segment of the working population.

Because domestic servants were employed and (usually) actually lived in the homes of their employers, relations between servants and mistresses or masters generally followed a paternalist model; servants lived in the home, so they could be represented as part 
of the family. 6 If servants were part of the "family," however, they were clearly positioned as dependent children who needed constant supervision in return for the protection and patronage they were supposed to need and enjoy. In the Victorian period, in fact, the idealized middle-class home, where a kindly but firm and efficient mistress exercised benevolent surveillance over and taught middle-class moral and economic values to loyal and deferential servants, was often represented as the last bastion of paternalist social relations and as the best hope for the moral reform of the working classes. Trained in domestic skills and morality through the influence of middle-class mistresses, servants, it was hoped, would marry working men and recreate model British homes on a smaller scale, thereby defusing social conflict and producing a strong and contented labor force. The proliferation of manuals on how to manage servants, authored by both women and men, testifies to the importance many Victorians attached to the process of inculcating proper values in servants and to the significant role played by the middle-class mistress in class relations. ${ }^{7}$

Factory workers, on the other hand, were supposedly ruled only by what Carlyle called the "cash nexus" (193). While they endured killing hours and were treated like machines while at work, whatever leisure hours they had were unsupervised and their dress, recreation, and personal relationships were left to their own discretion. In other words, although industrialism exploited workers and caused many of them immense suffering, it also gave them a frightening new kind of freedom. Except in cases where employers paid children's wages to their fathers (Tilly and Scott 110), even young children were inherently accorded a kind of adult autonomy and subjectivity quite different from the child-like position of domestic servants - and generally frightening to middle-class observers. However, if factory workers could be defined as servants, their lives could be brought under middle-class, specifically female, supervision. It should not be surprising, then, that middle-class female novelists tended to stress the difference between the living conditions and moral status of factory workers and servants, but to emphasize the essential likeness in the nature and background of the two groups.

In order to underscore the moral and physical superiority of domestic service over factory work, the domestic servants portrayed in the factory novels are almost always well-dressed, well-fed, happy, and loyal to the family, while factory workers are dirty, ragged, tired, usually hungry, and often hostile in their demeanor. In return for their supposedly superior living and working conditions, domestic servants in these novels willingly acquiesce in the paternalist model of social relations that requires them to repay their employers with deference and loyalty. Some servants are so loyal that they give up their own identities and become the trusted confidant(e)s and gatekeepers for their masters or mistresses. In most cases, in fact, the novels portray the servants themselves as the primary enforcers of traditional hierarchical relations both between and within classes. It is usually a servant, for instance, who decides whether a visitor will be allowed to enter through the front or back door, or even to speak to a member of the family. In Tonna's Helen Fleetwood, for instance, it is a servant who first remonstrates against and then actively prevents the factory owner's daughter speaking to the Widow Green, the matriarch of a family of factory workers. Dixon, Mrs. Hales's lifelong servant in Gaskell's North and South, devotes all her affection and emotional life to her mistress, and it is Dixon who is mainly responsible for enforcing the hierarchical relations among the master's family, the servants, and the factory workers who become part of their circle. 
Mary Barton provides an explicit example of the contrast typically drawn between the plenty of the domestic servant's life and the hunger of the factory operative. Gaskell describes the warmth and comfort of the kitchen through the eyes of the factory operative Wilson:

he was ushered into a kitchen hung round with glittering tins, where a roaring fire burnt merrily, and where numbers of utensils hung round, at whose nature and use Wilson amused himself by guessing. Meanwhile, the servants bustled to and fro; an out-door man-servant came in for orders, and sat down near Wilson; the cook broiled steaks, and the kitchen-maid toasted bread, and boiled eggs.

The coffee steamed upon the fire, and altogether the odours were so mixed and appetizing, that Wilson began to yearn for food to break his fast, which had lasted since dinner the day before. (106; ch. 6$)$

The "merrily" burning fire and the toasting bread, boiled eggs, and broiled steaks are a stark contrast not only to Wilson's own destitution, but even more to the scene he (along with the reader) has just left, the damp basement hovel of the dying displaced worker Davenport, which is the novel's most horrific description of the living conditions caused by industrialism.

Yet, despite the vast difference in their style of living, Wilson is not portrayed as essentially different from these prosperous servants. The "out-door man-servant" who sits next to him is essentially his double; the servant, too, has come to the master's house "for orders," and does not even look askance at the factory worker. Gaskell emphasizes the basic sympathy between factory worker and servant, and the likeness of both to the middle-class reader, when she comments:

If the servants had known [of Wilson's hunger], they would have willingly given him meat and bread in abundance; but they were like the rest of us, and not feeling hunger themselves, forgot it was possible another might. (106; ch. 6)

This sympathy is borne out a little later, when the cook, "who, when she had had time to think, after breakfast was sent in," does provide Wilson a meal before he leaves the house, having "noticed his paleness" (109-10; ch. 6). On the other side, Wilson overhears the coachman complaining about being left out in the bitter cold for two hours and the housemaids warning each other about their mistress's black temper this morning, learning that, despite their full stomachs, their lives are also at the mercy of the whims of their employers. Representing the servants and factory workers as basically sympathetic, though unfamiliar, to each other, as Gaskell does here, demonstrates the essential likeness of their natures and implies that the same kind, respectful, and benevolent treatment on the part of their middle-class employers would yield the same results in both home and factory - a contented and grateful labor force.

However, while novels like Mary Barton may occasionally offer a glimpse into the hardships of servant life, the main project of all the factory novels is, of course, to portray the horrors of factory life. All of them contain scenes that focus more or less graphically on the miserable and degrading conditions in which factory workers live and the monotonous, dehumanizing, and dangerous nature of the work they are forced to do. ${ }^{8}$ Once they 
have depicted these horrors, though, novelistic conventions demand that the victims be rescued into a happier life. Some of the factory novelists rescue their factory-worker protagonists by allowing them to move up into the middle or even aristocratic classes, as the characters in Mary Barton, Michael Armstrong, and Benjamin Disraeli's Sybil do; often, however, the only way this upward move can be represented is by sending the lower-class characters to the colonies (or at least out of England). Other factory novels can only offer the better world that follows a tragic death, which is the fate of at least three of the most sympathetic characters in Helen Fleetwood. In many cases, however, the greatest good fortune a factory worker can expect is to obtain a place as a servant. Particularly when a sympathetic middle-class character wants to aid an individual factory worker (or the child of one), the most desirable step is to get them into service - to turn them from factory workers into servants. In North and South, Margaret Hale fulfills her promise to the dying Bessy Higgins to take care of her sister Mary by hiring Mary as her servant, even though the girl is obviously unfit for the office and must receive thorough retraining to cure her of her mill-girl ways. The Widow Green in Helen Fleetwood is less fortunate; she laments that since she is unacquainted with any of the gentry in the town, she cannot "save" her grandchildren by sending them into service, and they must thus resign themselves to factory work. The clergyman she consults commiserates her situation, regretting that there are not nearly enough servant jobs to rescue all such deserving workers from the fate of being sent to the factories. The fact that historical evidence suggests that the reverse was more often the case - middle-class employers found it difficult to recruit servants in factory towns because factory wages were so much higher ${ }^{9}$ - indicates how important it was to these writers to represent domestic service as more desirable and advantageous than factory work.

Michael Armstrong provides the most overt example of the social benefits middleclass writers hoped would result from the training domestic servants received in middleclass homes. Trollope's novel, of course, graphically portrays the plight of factory workers - their squalid living conditions, the oppressiveness of the factory itself, and the disastrous physical and moral effects of factory life on the workers, especially children. ${ }^{10}$ Portraying such overwhelming degradation and poverty creates something of a problem for a novelist; how can she represent the workers as morally and physically debased and still make them appear sympathetic to her primarily middle-class readers? Trollope manages this, significantly, by making her protagonist the son of a former domestic servant. In the midst of the destitution and squalor of the factory slum, Michael's penniless and ailing mother nevertheless manages to create a little haven of cleanliness, order, and religion, thanks to her first-hand training as a servant in a middle-class home. Mrs. Armstrong, Michael's mother, thus represents exactly what many middle-class reformers hoped that taking lower-class servants into the homes of their "betters" would accomplish; trained in domestic skills and middle-class moral values, Mrs. Armstrong has succeeded in reproducing a scaled-down version of the ideal home even in the worst of conditions. Most importantly, she has also succeeded in inculcating these values and skills in her own young children, even though financial necessity has forced them into the factory at a very early age.

Despite having the proper values instilled in him by his mother, the former servant, however, young Michael finds himself classed with the other, supposedly morally depraved, factory workers. His father dead, his mother mortally ill, and his older brother 
crippled from factory work, Michael, though but a child, works manfully to support his destitute family. He seems an ideal candidate for the conventional rescue mission of the factory novel; accordingly, he is soon brought into the home of Sir Matthew Dowling, where he meets and lives with the servants. Given the positive example of his mother, the former servant, one might expect that Michael will receive similar improving and sympathetic treatment in Sir Matthew's home. However, he meets only with contempt from both the servants and the family into whose society he is thrown. The reader quickly realizes that the charity of Sir Matthew, the factory owner, is a sham, and that the rest of his family, including his wife and daughters, have no sense of their paternal duty toward the boy. The treatment Michael receives in their home is just the opposite of what Trollope and the other factory novelists advocated for both servants and factory workers. The one person who recognizes Michael's inherent goodness and does attempt to educate and aid him is Sir Matthew's ugliest daughter Martha, a young woman who comes the closest of anyone in the house to exemplifying the right kind of domestic values (her mother and sisters are dedicated only to dressing well and aping the aristocracy). Even Martha, however, inadvertently betrays poor Michael by cooperating with her father in having the boy kidnapped and sent to the infamous child-labor horror chamber, Deep Valley Mill, demonstrating the inadequacy even of benevolent motives in the face of the deplorable effects of a badly-run household. Thus, what seems like Michael's "rescue" turns out to be only further enslavement.

The novel, of course, eventually does rescue Michael from the factory, along with his brother and his friend Fanny. The character instilled in him by his mother leads him to withstand the deprivations, both physical and moral, of his desperate situation, and he manages a daring escape from Deep Valley Mill. He later returns to the Dowling home, braving the danger of recapture, to aid Martha Dowling in nursing her dying, bankrupt father, demonstrating the loyalty that good servants like his mother were supposed to feel towards their benevolent mistresses even in times of crisis when they could not be paid for their services. Michael is eventually rewarded with a good education and a middle-class life style, married to his female counterpart, Fanny.

More far-reaching than rescuing individual factory workers to a secure place within the middle-class home, however, is the attempt several of the factory novels make to recreate paternalism in the factory itself. The notion of establishing factories in accordance with paternalist principles was by no means unique to these writers; many Victorian social reformers advocated such an organization as a potential solution to industrial ills. Significantly, however, the model for paternalist relations portrayed in most of these novels is not the landed estate, but the middle-class home. Factory workers are even called "servants" by some characters, and specific analogies are drawn between women's treatment of servants and factory owners' treatment of their operatives. In North and South, for instance, where the narratives of political economy and paternalism are explicitly brought into direct opposition, the factory owner Mr. Thornton defends his treatment of his rebellious workers by comparing it to Margaret Hale's dealings with her servants. He asks, “'Do you give your servants reasons for your expenditure, or your economy in the use of your own money?" (117; ch. 15). Margaret, on the other hand, uses her experience of the interlocking paternalistic bonds that characterize her relations with servants to try to interpret the conflict between owner and operatives: "on the very face of it, I see two classes dependent on each other in every possible way, yet each evidently regarding the 
interests of the other as opposed to their own; I never lived in a place before where there were two sets of people always running each other down"' (118; ch. 15). Because she is accustomed to mutual respect and dependence between people who understand and accept their "place" in the order of things, Margaret has difficulty understanding the hostility she observes between the "masters" and the "hands." 11 Such problems would not exist, she implies, if men like Thornton would treat their employees like well-bred women treat their servants, recreating paternalistic bonds in the factory setting as well as the home.

Tonna is even more explicit in Helen Fleetwood about reproducing paternalism in an industrial setting when she imagines the daughters and wives of mill-owners exercising the same function for the family's factory "servants" as they presumably do for their domestic servants. These middle-class women, Tonna suggests, need only devote "two hours of their vacant morning"

to the sweet and sacred task of superintending the instruction of their young [factory] servants in religious and useful knowledge; shaming vice, overawing insolence, encouraging modesty, industry, and cleanliness, by the mere force of their frequent presence and occasional admonitions. A clean, airy room, regular arrangements, a few minutes allowed for thoroughly cleansing their soiled skin and brushing their clothes, with easy, but distinct tasks assigned, and suitable rewards for such as excelled - all under the personal direction of the employer's family: oh, what a refreshment to body and mind would this have secured to the poor little toil-worn creatures! by what a tie of respectful affection, and consequent diligence and integrity in his service, would it have bound them to their master! (116; ch. 13, emphasis added)

For writers like Tonna and her fellow factory novelists, representing factory workers as servants is both a potential solution to the "problem" of suffering, exploited factory workers and a way of claiming authority for middle-class women even in the supposedly more public world of the factory, by virtue of their experience as domestic managers of servants.

If all working-class people could be represented as servants who could be regulated and instructed in proper domestic values by middle-class women, it was, of course, equally important that middle-class women be taught the importance of fulfilling their own role properly. A number of recent feminist literary critics have discussed the many manuals, journal articles, essays, and novels aimed at convincing middle-class women that their domestic duties were crucial to the well-being of their families, their servants, and society. ${ }^{12}$ As we have observed in Michael Armstrong, the factory novelists frequently contributed to the instruction of middle-class women by portraying the results of the failure of such women to perform their domestic duties. The novels castigate women who devote their time exclusively to dressing, exchanging visits, and showing off their wealth in imitation of the idle aristocratic women they presumably desired to become. ${ }^{13}$ This is true of the wives and daughters of most of the factory owners depicted in the factory novels, but is perhaps most obvious in the Dowling household, where the failure of the mistress of the house is made manifest in the behavior of her servants. If, in Trollope's novel, the former servant Mrs. Armstrong actively represents the proper domestic values middleclass women hoped to instill in their servants, the servants in the Dowling household exemplify what happens when the mistress neglects that duty to her dependents. 
The Dowling servants, as we have seen, do believe in their own superiority to factory workers and hold firmly to the hierarchical arrangements typical of households organized according to the principles of paternalism. The Dowling household, however, is only a parody of paternal hierarchy, lacking the patronage and benevolence the mistress and master were supposed to offer and the gratitude and deference the servants were to yield in return. The servants' own relationships are characterized by bickering, envy, and scheming, while Lady Dowling largely ignores them and Sir Matthew openly flirts with and tempts the female servants. Sir Matthew's behavior exemplifies the chief horror decried by advocates of well-run domestic establishments, that female servants would seduce or be seduced by male family members. The servants also criticize and mock the family, especially Sir Matthew, comparing the Dowlings unfavorably with their previous masters or mistresses and freely admitting that the only reason they remain in the Dowlings' employ is the high wages they receive. When, at the end of the novel, Sir Matthew becomes bankrupt, all but one of the numerous household of servants immediately decamp to greener pastures without a pang, though some of them first accept a bribe from the second Mrs. Dowling to help her steal from her husband whatever she can carry away before his creditors arrive.

Trollope's portrayal of Sir Matthew's servants is meant to be humorous, but it is also revealing; the servants act out virtually every fear middle-class employers had about the behind-the-scenes actions of their household help. Further, the Dowling household demonstrates that the middle-class home itself could become infected with the market relations of capitalism. This is a crucial problem for middle-class female reformers like Trollope and the other authors of factory novels. For while their novels struggle to bring factory workers under the umbrella of the paternalist middle-class home, either literally or metaphorically, the force of the market is pulling in an opposite direction - to make loyal servants into waged "hands." Historically, the position of domestic servant did become more and more like that of other working-class people over the course of the nineteenth century, with more servants living outside the homes in which they worked and their relations with their employers increasingly regulated by contractual agreements rather than patronage and loyalty. ${ }^{14}$ For the writers I have been discussing, this prospect poses a threat not only to their vision of ideal social relations, but also to their own authority as mistresses of servants and mediators of class relations.

Nonetheless, Trollope, along with the other female factory novelists, does not give up on the mistress/servant relation as a model for class mediation. The problems "below stairs" at the Dowling household, in her representation, are traceable not to the paternalist model itself, but rather to Lady Dowling's abdication of her responsibilities. Significantly, the novel also includes Mary Brotherton, the novel's heroine, who is a model mistress to her servants, inspiring loyalty and respect from them even years after she has left the country; the coachman Michael meets on his return to Ashleigh still calls Miss Brotherton "our dear young lady" and expresses his gratitude at the pensions she left to "every one of her servants according to their length of service" (318; ch. 27). Mary, whose dealings with her servants are depicted in more detail earlier in the novel, treats her dependents with firmness but respect, educating, protecting, and aiding them in the best paternalistic style. Through her experiences in the course of the novel, which include extensive firsthand research into factories like those from which her own fortune is derived, Mary comes to believe that it is the paternalistic relations practiced by the country gentry, on which her 
own household relations have been based, that hold out most hope for the improved welfare of factory workers (98; ch. 10).

Mary Brotherton is a mill-owner's daughter who, like the daughters of factory owners in virtually all the factory novels, has been "protected" from the vulgar and supposedly contaminating world of the factory for most of her life. Having her come to this realization sends a strong message to the novel's middle-class female readers about their own duties and responsibilities as current or future managers of lower-class workers, whether in households staffed by domestic servants or in the factories run by their fathers and husbands. Their domestic skills are crucial to the smooth functioning of relations between classes. Thus characters such as Amelia Z., the daughter of the mill-owner in Helen Fleetwood, may feel sympathy with factory workers and attempt to extend charitable alms to them, but the bad example of Lady Dowling and the positive example of Mary Brotherton, as well as other model domestic managers like Gaskell's Margaret Hale, show that sympathy is not enough; if middle-class women intend to fulfill the important role allotted them as mediators of class relations, they must take control of their own homes and make sure that the employer-employee relations there are based on paternal bonds rather than the market relations that have poisoned class relations in the factories, mills, and businesses run by men.

While virtually all the women factory novelists imagine the paternalistic mistress/servant relation as a model for class relations in both home and factory, none of the novels actually represents the intervention of middle-class women in a real factory setting. Mary Brotherton, despite her extensive knowledge of factory conditions, fails to effect any changes in the factory system itself, and Michael Armstrong ends with her retreat from industrial England to an almost-classless mini-society in Germany — almost classless, that is, because although the factory workers she has rescued have become her equals, they are all still served by grateful and loyal servants. ${ }^{15}$ North and South, written some fifteen years later, does represent its heroine as influencing some change in the arrangements of a factory, but the changes do not exactly follow a paternalist model.16 Although Tonna has one of her characters imagine a paternalistic factory with the owner's wife and daughters benevolently instructing the workers, the factories she actually portrays utterly fail at achieving such harmony, and the best ending she can depict for her factory-worker characters is a martyr's death or a return to the country. Because the conventions and conditions of their historical moment prevented these women writers from resolving the issues raised in their novels by radically reconstructing factories and public workplaces, most of them, not surprisingly, turned instead to the novelistic conventions of the romance plot to achieve some kind of resolution. While ending a factory novel with a marriage or a series of marriages - does not in itself constitute a workable solution to the serious social problems raised by the novels, the romantic marriage ending allows for a sense of closure and often offers a kind of compromise between the conflicting narratives of domestic and political economy.

The fact that the social relations advocated by this important group of novelists seem to have had little actual effect on class relations in factories, however, does not negate the cultural work they performed. By drawing attention to the abuses of the factory system, especially for children and women workers, and by representing factory workers in conjunction with domestic servants, they demonstrated to thousands of middle-class readers that the factory "hands" most of them found unfamiliar, frightening, and even 
dangerous were not essentially different from the familiar working-class people in their own homes. Only their working conditions and the treatment they received from their employers made them seem innately immoral, improvident, and hostile. By increasing sympathy for factory workers, the factory novels demonstrably contributed to protective legislation, if not to reformed paternalistic factories, and helped to teach their female readers that their own role involved more than being decorative symbols of their fathers' and husbands' prosperity.

Reading these novels as a debate between two different sides of the middle class that is, the hiring class - shows how novelistic representations worked not only to construct readers' understanding of the positions, needs, and conflicts of the groups they supervised but also to shape the attitudes and duties of the middle classes to which they belonged themselves. In addition, by stressing the essential likeness between middle-class and working-class women, whether servants or factory workers, particularly their ability to learn domestic skills and manage ideal homes in any setting, the novels helped to reinforce an identity for women that crossed class lines. In doing so, they contributed indirectly to the increased array of cultural possibilities that gradually opened for women of all classes over the course of the century.

The University of Kansas

\section{NOTES}

1. Both factory workers and domestic servants came primarily from rural backgrounds, their parents or grandparents having been agricultural workers. The factory workers in Mary Barton, for instance, are represented as nostalgic for their rural past. This is most obvious in the case of Alice Wilson, whose final days of life are spent in a dream-like vision of her rural childhood, but many of the other characters also occasionally comment on and express longing for their rural past. Historians report that as many as two-thirds of the domestic servant force were also daughters of agricultural laborers (Tilly and Scott 108; McBride 10).

2. See especially Harsh, Kestner, Newton, Shrivastava, and Zlotnick. There were, of course, male factory novelists as well, including Benjamin Disraeli, Charles Kingsley, and Charles Dickens, but my focus here is primarily on the female authors.

3. Trollope, for instance, took a fact-finding tour to Manchester, where she visited factories and interviewed and entertained labor activists and reformers (Heineman 169-70). Some factory novelists, including Gaskell and Stone, had first-hand knowledge of their subject because they lived in manufacturing districts and visited factory workers personally. Others based their novels on Parliamentary blue-books (see Brantlinger, and Kovacevic and Kammer).

4. A large majority of domestic servants in nineteenth-century Britain were, like their middleclass mistresses, female. Historian Pamela Horn reports that in 1851, there were 74,000 male domestic servants in England, compared to three-quarters of a million female servants (71). Leonore Davidoff and Catherine Hall estimate that 82 per cent of servants in middle-class households were female (388). McBride suggests that the fact that so many domestic servants were female is one reason they have been neglected by historians and scholars (9).

5. Most historians of domestic service rely on either the published reports or the original enumerators' records of the 1851 and 1871 Occupational Census for their estimates of numbers of servants in the nineteenth century (see Hill 7, 42; Higgs 128; Roberts 17-18). It should be stressed, however, that the census records are somewhat unreliable and open to interpretation (Roberts 17). 
6. For a discussion of servants and paternalism, see Robbins (42-43). On the implications of paternalism for middle-class women in the nineteenth century, see Armstrong (91) and Bodenheimer (21-22).

7. For a discussion of domestic manuals on managing servants, see Elizabeth Langland's Nobody's Angels, especially 51-52 and 74-76.

8. Mary Barton is somewhat unique in also portraying the positive side of factory life. Although the novel does include scenes of extreme misery, much of the novel focuses on the relative freedom and some of the pleasures of working-class culture.

9. Tilly and Scott report, for instance, that "there were barely any domestic servants in the textile towns," citing the example of Preston, where "[o]nly 3 percent of the population over age fifteen" were servants in 1851 (83).

10. On Michael Armstrong's portrayal of factories and child labor, see especially Chaloner and Heineman.

11. Robbins points out that in precapitalist society, "all laborers were servants." The Industrial Revolution, however, "replaced the servant and man by the 'operative' and 'hand,' except of course the (mainly female) domestic servant" (42).

12. On the increasing importance placed on women's domestic role, see Poovey, Langland, and Cohen.

13. This is, of course, a rather anachronistic view of aristocratic women. For the ideological significance middle-class writers attached to the image of the vain, idle aristocratic woman, see Armstrong (5). For a historical view of the changing role of aristocratic women in the nineteenth century, see Gerard.

14. See McBride (30-31), Robbins (42-43), and Horn (109).

15. Harsh suggests that the new society Mary creates in Germany is virtually classless (110). While she does note that this "classlessness" is qualified by Mary's continuing control of the purse-strings, she fails to notice that Mary's household is still upheld by the labor of domestic servants.

16. See my article, "The Marriage of Classes in Gaskell's North and South."

\section{WORKS CITED}

Armstrong, Nancy. Desire and Domestic Fiction: A Political History of the Novel. New York: Oxford UP, 1987.

Bodenheimer, Rosemarie. The Politics of Story in Victorian Social Fiction. Ithaca: Cornell UP, 1988.

Brantlinger, Patrick. "Bluebooks, the Social Organism, and the Victorian Novel," Criticism 14 (Fall 1972): 328-44.

Brontë, Charlotte. Shirley. 1849. Oxford: Oxford UP, 1981.

Carlyle, Thomas. "Chartism.” Thomas Carlyle: Selected Writings. Ed. Alan Shelston. NY: Viking Penguin, 1971. 151-232.

Chaloner, W. H. "Mrs. Trollope and the Early Factory System," Victorian Studies 4 (1960): 159-66.

Cohen, Monica. Professional Domesticity in the Victorian Novel: Women, Work and Home. Cambridge: Cambridge UP, 1998.

Davidoff, Leonore, and Catherine Hall. Family Fortunes: Men and Women of the English Middle Class, 1780-1850. Chicago: U of Chicago P, 1987.

Disraeli, Benjamin. Sybil or The Two Nations. 1845. Oxford: Oxford UP, 1981.

Eliot, George. Felix Holt, The Radical. 1866. New York: Penguin, 1972.

Elliott, Dorice Williams. "The Marriage of Classes in Gaskell's North and South," Nineteenth-Century Literature 49 (June 1994): 21-49.

Gaskell, Elizabeth. Mary Barton: A Tale of Manchester Life. 1848. New York: Penguin, 1970. 
- North and South. 1855. Oxford: Oxford UP, 1973.

Gerard, Jessica. Country House Life: Family and Servants, 1815-1914. Oxford: Blackwell, 1994.

Harsh, Constance D. Subversive Heroines: Feminist Resolutions of Social Crisis in the Condition-ofEngland Novel. Ann Arbor: U of Michigan P, 1994.

Heineman, Helen. Mrs. Trollope: The Triumphant Feminine in the Nineteenth Century. Athens, $\mathrm{OH}$ : Ohio UP, 1979.

Higgs, Edward. "Domestic Service and Household Production." Unequal Opportunities: Women's Employment in England 1800-1918. Ed. Angela V. John. Oxford: Basil Blackwell, 1986. 125-52.

Hill, Bridget. Servants: English Domestics in the Eighteenth Century. Oxford: Clarendon, 1996.

Horn, Pamela. The Rise and Fall of the Victorian Servant. New York: St. Martin's P, 1975.

Jewsbury, Geraldine. Marian Withers. 3 vols. London: Colburn, 1851.

Keating, P. J. The Working Classes in Victorian Fiction. London: Routledge and K. Paul, 1971.

Kestner, Joseph. Protest and Reform: The British Social Narrative by Women, 1827-1867. Madison: $\mathrm{U}$ of Wisconsin P, 1985.

Kovacevic, Ivanka, and Barbara Kammer. "Blue Book into Novel: The Forgotten Industrial Fiction of Charlotte Elizabeth Tonna." Nineteenth-Century Fiction 25 (Sept. 1970): 152-73.

Langland, Elizabeth. Nobody's Angels: Middle-Class Women and Domestic Ideology in Victorian Culture. Ithaca: Cornell UP, 1995.

Martineau, Harriet Martineau. A Manchester Strike. Illustrations of Political Economy, vol. 3. London: Charles Fox, 1834.

McBride, Theresa M. The Domestic Revolution: The Modernisation of Household Service in England and France 1820-1920. New York: Holmes \& Meier, 1976.

Newton, Judith Lowder. Women, Power, and Subversion: Social Strategies in British Fiction, 1778-1860. Athens: U of Georgia P, 1981.

Poovey, Mary. Uneven Developments: The Ideological Work of Gender in Mid-Victorian England. Chicago: U of Chicago P, 1988.

Robbins, Bruce. The Servant's Hand: English Fiction from Below. New York: Columbia UP, 1986.

Roberts, Elizabeth. Women's Work 1840-1940. Houndsmills, Basingstoke, Hampshire: Macmillan, 1988.

Sharpe, Pamela. Adapting to Capitalism: Working Women in the English Economy, 1700-1850. New York: St. Martin's P, 1996.

Shrivastava, Dr. K. C. Women Novelists: Their Contribution to the Proletarian Novel in the Victorian Age. Salzburg Studies in English Literature: Romantic Reassessment. Ed. James Hogg. Salzburg: Institut fur Anglistik und Amerikanistik, 1985.

Stone, Elizabeth. William Langshawe, the Cotton Lord. 2 vols. London: Richard Bentley, 1842.

Tilly, Louise A., and Joan W. Scott. Women, Work, and Family. New York: Holt, Rinehart and Winston, 1978.

[Tonna], Charlotte Elizabeth. Helen Fleetwood. The Works of Charlotte Elizabeth. Vol. 2. New York: Dodd, 1844.

Trollope, Mrs. Frances. The Life and Adventures of Michael Armstrong, the Factory Boy. 1840. Newcastle-on-Tyne: John Christie, 1876.

Valenze, Deborah. The First Industrial Woman. New York: Oxford UP, 1995.

Zlotnick, Susan. Women, Writing, and the Industrial Revolution. Baltimore: Johns Hopkins UP, 1998. 